cytoplasm and larger nuclei with more prominent nucleoli.

Such findings are in contrast to those reported by both cases with $V C L / A L K$ fusion. The right kidney tumor from Marino-Enriquez et $a l^{3}$ had a focal reticular growth pattern, prominent lymphoplasmacytic infiltrate, stromal desmoplasia and solid sheet of polygonal-to-spindle cells with vesicular nuclei and abundant eosinophilic cytoplasm with intracytoplasmic lumina. The immunohistochemistry profile included expression of EMA and the cytokeratins MNF116, AE1/AE3 and CAM5.2, as well as maintaining nuclear INI-1 expression. The final pathological diagnosis was renal medullary carcinoma (RMC). In the study by Debelenko et al, ${ }^{2}$ the initial needle-core biopsy finding was RMC of sickle cell trait. Analysis of a nephrectomy specimen 5 months later was described as having solid and diffuse sheet-like growth of large polygonal-to-round tumor cells with abundant and vaguely granular eosinophilic cytoplasm characterized by intracytoplasmic lumina and moderately pleomorphic clear nuclei and small nucleoli, occasional grooves and rare vacuoles. Immunohistochemistry demonstrated tumor cell expression of EMA, the cytokeratins AE1/ AE3, CAM5.2 and CK7, as well as INI-1 expression, whereas CD10, renal antigen, S-100, HMB45 and WT1 were negative. The final pathological diagnosis was renal cell carcinoma of indeterminate subtype.

It is important to note that RMC often demonstrates significant variation in the microscopic appearance. Considering this, combined with the overlap in patient demographics, pathological features and especially the new genetic results from these two published cases, it suggests that the tumor from the Debelenko et $a l^{2}$ study may be within the RMC spectrum.
In summary, $A L K$ rearrangement in papillary renal cell carcinoma cases in older adults may represent a distinct pathological entity with poorer outcome. Our cases did not have VCL as a partner and TFE3 was not disrupted. This is in contrast to all previously described categories, including kidney tumors with $V C L / A L K$ fusion in young black males with sickle cell trait. Such distinction of $A L K-$ rearranged pathological entities is of particular importance because of the potential benefit from $A L K$ inhibitor therapy in these patients.

\section{Disclosure/conflict of interest}

The authors declare no conflict of interest.

Jennelle C Hodge, Kathryn E Pearce and
William R Sukov
Department of Laboratory Medicine and Pathology,
Mayo Clinic, Rochester, MN, USA
E-mail: hodge.jennelle@mayo.edu

\section{References}

1 Sukov W, Hodge J, Lohse C, et al. ALK alterations in adult renal cell carcinoma: Frequency, clinicopathologic features and outcome in a large series of consecutively treated patients. Mod Pathol 2013 (in press).

2 Debelenko LV, Raimondi SC, Daw N, et al. Renal cell carcinoma with novel VCL-ALK fusion: new representative of ALK-associated tumor spectrum. Mod Pathol 2011;24:430-442.

3 Marino-Enriquez A, Ou WB, Weldon CB, et al. ALK rearrangement in sickle cell trait-associated renal medullary carcinoma. Genes Chrom Cancer 2011;50: 146-153.

Supplementary Information accompanies the paper on Modern Pathology website (http://www.nature.com/ modpathol)

\title{
Reply to 'Distinct ALK-rearranged and VCL-negative papillary renal cell carcinoma variants in two adults without sickle cell trait'
}

Modern Pathology (2013) 26, 605-607; doi:10.1038/modpathol.2013.37

To the editor: ALK activation by chromosomal rearrangement in renal cell carcinoma (RCC) was first demonstrated by two independent pediatric pathology studies 2 years ago. ${ }^{1,2}$ These reports coincided with the successful results of the clinical trial that tested targeted therapy with crizotinib in ALK-positive lung cancer. ${ }^{3}$ Consequently, two recently published large series of adult RCCs cumulatively identified four new $A L K$-rearranged tumors. ${ }^{4,5}$ Current data, combined from four independent studies during 2010-2012, include six ALKrearranged tumors in a representative cohort of 884 RCCs of main morphologies arising in pediatric and adult patients of diverse ethnicities (Table 1). 
Table 1 Clinicopathologic characteristics and fusion partners of ALK-rearranged renal cell carcinomas

\begin{tabular}{|c|c|c|c|c|c|c|c|c|}
\hline \multirow[t]{2}{*}{ Study } & \multirow{2}{*}{$\begin{array}{l}\text { Number } \\
\text { of cases } \\
\text { studied }\end{array}$} & \multicolumn{7}{|c|}{$A L K$-rearranged cases } \\
\hline & & \# & $\begin{array}{l}\text { Patient's age } \\
\text { and sex }\end{array}$ & Patient's ethnicity & $\begin{array}{l}\text { Stage of } \\
\text { disease }\end{array}$ & $\begin{array}{l}\text { Tumor } \\
\text { morphology }\end{array}$ & $\begin{array}{l}\text { Fusion } \\
\text { partner }\end{array}$ & Follow-up \\
\hline Debelenko et al ${ }^{1}$ & 6 & 1 & 16 Years, M & African-American & III & Unclassified $^{\mathrm{a}}$ & $V C L$ & 9 Months, NED \\
\hline Mariño-Enríquez et $a l^{2}$ & 1 & 1 & 6 Years, M & African-American & II & Medullary ${ }^{\mathrm{a}}$ & $V C L$ & 21 Months, NED \\
\hline \multirow[t]{2}{*}{ Sugawara et $a l^{4}$} & 343 & 2 & 36 Years, F & Japanese & $\mathrm{I}$ & Unclassified & TPM3 & 2 Years, NED \\
\hline & & & 53 Years, F & Japanese & I & Papillary type 2A & EML4 & 3 Years, NED \\
\hline \multirow[t]{2}{*}{ Sukov et $a l^{5}$} & 534 & 2 & 61 Years, M & Unknown & I & Papillary & $\begin{array}{l}\text { Unknown, } \\
\text { not } V C L\end{array}$ & 4 Years, DOD \\
\hline & & & 59 Years, M & Unknown & I & Papillary & $\begin{array}{l}\text { Unknown, } \\
\text { not } V C L\end{array}$ & 1.4 Years, DOD \\
\hline Total & 884 & $6(0.7 \%)$ & & & & & & \\
\hline
\end{tabular}

DOD, died of disease; F, female; M, male; NED, no evidence of disease.

${ }^{a}$ Retrospective analysis indicates similar morphology of the tumors.

The overall frequency of $A L K$ rearrangement in RCC is low (approximately $0.7 \%$ ) and no rearrangement has been detected in 505 cases of clearcell RCC. ${ }^{4,5}$ Further studies should clarify whether the molecular mechanism of clear-cell RCC governed by loss of VHL and ALK activation are mutually exclusive. Hereditary and some sporadic papillary RCCs are driven by MET tyrosine kinase, ${ }^{6}$ and testing of both kinases in papillary RCCs appears to be rational especially because crizotinib combines anti-ALK and anti-MET activities.

Sukov et $a l^{5}$ found substantial proportions of both clear-cell and papillary RCCs with increased $A L K$ gene copy numbers that correlated with poorer outcome in the clear-cell subtype. $A L K$ amplifications with activating point mutations are known to occur in neuroblastomas; ${ }^{7}$ it would be interesting to explore a possibility of this mechanism in RCCs with $A L K$ amplifications.

All authors paid close attention to morphologic and clinical features of ALK-positive RCCs and the handful of cases shows several trends. Thus, both pediatric cases affected children of African-American descend caring the sickle cell trait; the tumors were arising in the renal medulla and exhibited similar morphologies. Mariño-Enríquez et $a l^{2}$ classified their tumor as renal medullary carcinoma (RMC); we ${ }^{1}$ did not label ours as RMC because it lacked extreme clinical aggressiveness characteristic of RMC. ${ }^{8,9}$ Retention of INI1 by immunohistochemistry was also not in favor of RMC. ${ }^{10}$ In a retrospect, both pediatric cases shared all clinicopathologic characteristics and the same $V C L-A L K$ fusion. A consensus should be reached whether they belong to the least aggressive part of the RMC spectrum or favorable clinical course and intact INI1 are significant enough to distinguish them from RMCs.

Three of four adult cases had papillary morphology. The case of Sugawara et $a l^{4}$ was classified as papillary type $2 \mathrm{~A}$ and cases of Sukov et $a l^{5}$ as papillary with clear eosinophilic cytoplasm; all three tumors were positive for CK7. The ALK fusion partner of the papillary type 2A RCC of Sugawara et $^{4} l^{4}$ was EML4, implicated in most of the cases of pulmonary ALK-associated carcinoma; fusion partner(s) of cases of Sukov et $a l^{5}$ are not known, but VCL, participating in pediatric ALKpositive RCCs, was excluded. The 4th adult ALKpositive RCC had different variant morphology and TPM3 as the ALK fusion partner. ${ }^{4}$

Thus, five of six ALK-positive RCCs cluster in two groups: two $V C L-A L K$-positive pediatric tumors with characteristic histology (solid growth, abundant eosinophilic cytoplasm, intracytoplasmic lumina) and three adult tumors with papillary architecture and other than $V C L-A L K$ fusion partner(s). Morphologic spectrum of ALK-rearranged tumors, however, is not limited to these two groups. The common feature of all ALK-positive RCCs is eosinophilic cytoplasm mentioned in all studies, ${ }^{1,2,4,5}$ but this characteristic is hardly specific. It appears that prediction of $A L K$ rearrangement cannot be accurately drawn from tumor histology and at this time it would be impractical to recognize ALK-positive RCC as a separate pathologic subtype. However, the broader availability of new generation technologies may change the current tumor classification faster than we think and ALK-positive carcinomas, or ALKomas, will find their niche.

The overall 5-year survival of renal cancer is $70.6 \%$; however, $17 \%$ of patients have distant metastatic disease and in this group the 5-year survival is only $11.6 \% .{ }^{11}$ Thus, although the frequency of $A L K$ rearrangement in RCC is low, patients with distant metastatic disease can be tested and, if positive, tried with crizotinib or other ALK inhibitors to determine whether targeted therapies are as effective in RCC as they proved in pulmonary adenocarcinoma. 


\section{Disclosure/conflict of interest}

The authors declare no conflict of interest.

Larisa V Debelenko

Department of Pathology, Children's Hospital of Michigan-Wayne State University, Detroit, MI, USA E-mail: ldebelen@med.wayne.edu

\section{References}

1 Debelenko LV, Raimondi SC, Daw N, et al. Renal cell carcinoma with novel VCL-ALK fusion: new representative of ALK-associated tumor spectrum. Mod Pathol 2011;24:430-442.

2 Mariño-Enríquez $\mathrm{A}$, Ou WB, Weldon $\mathrm{CB}$, et al. ALK rearrangement in sickle cell trait-associated renal medullary carcinoma. Genes Chromosomes Cancer 2011;50:146-153.

3 Kwak EL, Bang YJ, Camidge DR, et al. Anaplastic lymphoma kinase inhibition in non-small-cell lung cancer. N Engl J Med 2010;363:1693-1703.

4 Sugawara E, Togashi Y, Kuroda N, et al. Identification of anaplastic lymphoma kinase fusions in renal cancer: large-scale immunohistochemical screening by the intercalated antibody-enhanced polymer method. Cancer 2010;118:4427-4436.

5 Sukov WR, Hodge JC, Lohse CM, et al. ALK alterations in adult renal cell carcinoma: frequency, clinicopathologic features and outcome in a large series of consecutively treated patients. Mod Pathol 2012;25:1516-1525.

6 Schmidt L, Junker K, Nakaigawa N, et al. Novel mutations of the MET proto-oncogene in papillary renal carcinomas. Oncogene 1999;18:2343-2350.

7 George RE, Sanda T, Hanna $\mathrm{M}$, et al. Activating mutations in ALK provide a therapeutic target in neuroblastoma. Nature 2008;455:975-978.

8 Davis CJ Jr, Mostofi FK, Sesterhenn IA. Renal medullary carcinoma. The seventh sickle cell nephropathy. Am J Surg Pathol 1995;19:1-11.

9 Perlman EJ. Pediatric renal cell carcinoma. Surg Pathol Clin 2010;3:641-651.

10 Cheng JX, Tretiakova M, Gong C, et al. Renal medullary carcinoma: rhabdoid features and the absence of INI1 expression as markers of aggressive behavior. Mod Pathol 2008;21:647-652.

11 Howlader N, Noone AM, Krapcho M, et al. SEER Cancer Statistics Review, 1975-2009 (Vintage 2009 Populations). National Cancer Institute: Bethesda, MD, http://seer.cancer.gov/csr/1975_2009_pops09/ based on November 2011 SEER data submission, posted to the SEER web site, 2012.

\section{HER-2 intratumoral heterogeneity}

Modern Pathology (2013) 26, 607-609; doi:10.1038/modpathol.2012.147

To the editor: We read with great interest the paper published by Seol $\mathrm{H}$ et $a l^{1}$ concerning HER-2 intratumoral heterogeneity $(\mathrm{IH})$ in breast cancer.

Nowadays most pathologists involved in HER-2 characterization in breast cancer more or less frequently have to deal with cases of $\mathrm{IH}$ in the everyday routine.

While reading this article, we asked ourselves the following question: "which could be the best way to write the report for the clinicians?'.

At the present time, our Lab-FISH report shows synthetically if the tumour sample is found to be amplified or unamplified; however, if focal-amplified neoplastic clones are seen, in accordance with what has been recently established in an Italian consensus conference, ${ }^{2}$ the percentage of cells with overexpression of the protein or gene amplification (Her-2/CEP-17 ratio $>2$ or number of HER-2 copies $>6$ or HER-2 clusters), even if less than $10 \%$, should be added in the report.

So far we have noted however that one 'final' question most clinicians frequently ask to us is: 'how should I consider it amplified or non-amplified?'.

This is likely to be due to the legislation regulating the administration of the drug (http://www.agenziafarmaco.gov.it/it/content/trastuzumab) according to which 'Herceptin should be used only in patients whose tumours show HER-2 overexpression or
HER-2 gene amplification as determined by an accurate and validated test'.

The same situation occurs for gastric and gastroesophageal junction adenocarcinomas for which the law provides the following: 'Trastuzumab should be administered only to patients with metastatic gastric cancer whose primary tumours exhibit HER-2 overexpression, defined as IHC $3+$ or IHC $2+$ together with a positive SISH or FISH result'.

So they both only refer to HER-2 protein overexpression and/or gene amplification and make no mention at all of a possible IH.

We believe that a reasonable way to document HER-2 IH could be to attach the FISH count results to the report and to close the report with a final interpretation of the results obtained. In agreement with Albarracin et $a{ }^{3}{ }^{3}$ we think that an analytical report completed with a critical evaluation of the results about HER-2 genetic heterogeneity (GH) should be worldwide promoted.

In accordance with the recently published guidelines, ${ }^{4,5}$ FISH report should describe: (a) the number of cells analysed; (b) the HER-2 gene copy number per nucleus; (c) the CEP17 copy number per nucleus; (d) the HER-2/CEP17 ratio for each nucleus; (e) the overall average ratio and the s.d.; (f) the number and the percentage of cells, if any, with ratio $>2.2$, and finally $(\mathrm{g})$ the average ratio in this group of cells. 